811.161.2'373:821.161.2.09

Т. І. Вавринюк

\title{
ТЕРМІНИ В ПОЕТИЧНИХ ТВОРАХ ЛІНИ КОСТЕНКО
}

Вавринюк Т. І. Терміни в поетичних творах Ліни Костенко.

У статті йдеться про особливості використання термінів у поетичних творах Ліни Костенко. Визначено, що терміни в поезії Ліни Костенко відображають науковотехнічний прогрес, обізнаність ліричної героїні 3 сучасними технологіями, виступають логіко-смисловими центрами різного роду метафоричних побудов.

Ключові слова: терміни, метафора, метонімія, епітет, алегорія. 
Вавринюк Т. И. Термины в поэтических произведениях Лины Костенко.

В статье рассматриваются особенности использования терминов в поэтических произведениях Лины Костенко. Отмечено, что термины в поэзии Лины Костенко отображают научно-технический прогресс, осведомленность лирической героини с современными технологиями, выступают логико-смысловыми центрами всякого рода метафорических конструкций.

Ключевые слова: термины, метафора, метонимия, эпитет, аллегория.

Vavrynyuk T. I. Terms in poetic works of Lina Kostenko.

Speech goes in the article about the features of the use of terms in poetic works of Lina Kostenko. Certainly, that terms in the poetry of Lina Kostenko represent scientific and technical progress, knowledge of lyric heroine with modern technologies, come forward as logicaly- semantic focis of different sort of metaphorical constructions.

Key words: terms, metaphor, metonymy, epithet, allegory.

Образність (багатозначність) слова 3 семантичної точки зору пояснюється законом асиметрії знака i значення. Знак і значення звичайно повністю не заміщують один одного: знак «прагне» мати інші функції, ніж власна, а значення прагне до того, щоб виразитися іншими засобами, ніж його власний знак. Ця асиметрія пояснює механізм семантичних трансформацій, яких зазнають однозначні «необразні» слова в художньому контексті.

До таких нео́бразних слів відносяться, зокрема, терміни, але лише в межах конкретної терміносистеми; коли ж вони потрапляють за іiі межі, - розширюють свою семантичну структуру і зближуються із загальновживаними словами. Найбільш сприятливі умови для цих процесів надає, на нашу думку, художній стиль.

Зауважимо, що особливості функціонування термінів у художньому мовленні вивчали Т. В. Катиш [21], В. І. Мінасян [4], Г. К. Молодід [3]. Як засіб мовної експресії терміни досліджував В. А. Чабаненко [6]. Науковці зазначають, що вживання терміна в художньому тексті свідчить про його функціональну рівність по відношенню до інших слів загальної мови, а також про те, що він у загальномовному вживанні поступово стає звичним засобом образного мислення, що лежить в основі художнього стилю [3, с. 8]. Отже, у художньому стилі термін може втрачати свої специфічні ознаки, набуваючи додаткових, а то й зовсім інших, смислових значень, він виступає елементом образної системи мови. У новому стильовому контексті термін, неемоційний за своєю природою, може розвивати емоційно-експресивні відтінки і конотації.

Використання термінів у художній літературі зумовлене тим (c) Т. І. Вавринюк, 2012. 
завданням, яке ставить той чи той автор, його естетичним смаком i майстерністю. У тексті твору терміни виконують певні стилістичні функції. У художньому творі використовуються терміни, що дають загальне уявлення про факти громадської, виробничої, наукової та іншої діяльності, яка описується художником. Ці терміни не $є$ результатом логічних доказів, що слідують один за одним. Вони виступають лише в якості характеристики явища і служать одним із засобів створення необхідного колориту.

У поетичному мовленні Ліни Костенко термінологічні слова i словосполучення вжито у двох планах: 1) прямому, без спеціальної стилістичної настанови і 2) переносному, як елемент індивідуальноавторської метафори.

Слід підкреслити, що термінологіна лексика в прямому значенні в досліджуваних творах трапляється рідко. Вона потрібна в основному для відтворення реальних подій і змалювання особливостей сучасної епохи: Ближчий мені старий Гайявата, Ніж всі досягнення кібернетики. Ну, космос, ну, комп'ютер, нуклеӥни (2, с . 33).

Авторка використовує гру слів, спираючись на фонетичну співзвучність частки «ну» 3 частиною кореня слова нуклеїни, що створює звуковий ефект. Отже, можна сказати, терміни в поезії Ліни Костенко відображають науково-технічний прогрес, обізнаність ліричної героїні 3 сучасними технологіями, виступають логікосмисловими центрами різного роду метафоричних побудов: Але 3 усмішки, з потиску рук, з брехні, убитої наповал, історія найскладніша з наук - обчислює ЗОРЯНИЙ ІНТЕГРАЛ.

...Вища математика віку: 3 СУМИ БЕЗКОНЕЧНО МАЛИХ ВИНИКАС БЕЗКОНЕЧНО ВЕЛИКЕ (2, с. 157); Якщо я маю біцепси душі - то в результаті сутичок із вами,..якщо мене ви й зігнете в дугу, то ияя дуга, напевно, буде вольтова (2, с. 150); І як для нас иүікаві ті галактики, звідкіль сигнал ніхто не передав... (2, с. 421).

Нашу увагу привертають ті семантичні перетворення термінів, які виступають як художньо-зображальні засоби в ролі складових елементів тропів.

Зазначимо, що в семантичній структурі терміна - елемента метафоричної конструкції, відбуваються зміни, які ведуть до виникнення елементів нового значення. Пряме, основне значення, ускладнюється i сприймається вже як переносне, контекстуальне. Джерелом образності $є$ взаємодія в одному термінослові двох типів лексичних значень - прямого 
i контекстуального. В індивідуально-авторській метафорі переносне значення не закріплюється за словом, характеризується перехідністю і можливе тільки в певному контексті. Наприклад: Грунтознавство осипалося під ногами, Орнітологія каркала на тополях (2, с. 393).

Так, терміни грунтознавство та орнітологія вжито в метонімічному значенні: під терміном грунтознавство розуміється земля, а під терміном орнітологія - птахи, зокрема ворони.

Спеціальні слова і сполуки в поетичному мовленні Ліни Костенко є елементами оригінальних метафор й епітетів, зокрема таких, що персоніфікують позначуваний терміном об'єкт, наділяють його рисами живої істоти. Наприклад: У тузі вічної розлуки супутник людям голос подає (2, с. 5); Нехай тендітні пальиі етики торкнуть вам серце і вуста (2, с. 28).

Оскільки особливістю художньої мови Ліни Костенко є яскраво виражена асоціативність мислення, то це позначається і на вживанні термінологічної лексики, яка виступає переважно у складі метафоричних мовних образів. Характер образних асоціацій у поетеси дуже неоднорідний. Одні асоціації пов'язані зі значенням терміна. Вони виникають саме як результат застосування термінологічного поняття в якійсь іншій, не пов'язаній $з$ цією терміносистемою, сфері діяльності суспільства. Підставою для такого перенесення терміна якраз і є близькість його значення до понять певної галузі людських стосунків. Як правило, термінологічне слово набуває при цьому більш узагальненого, значно ширшого від свого термінологічного поля, значення. Проте основна його сема зберігається і стає основою художнього образу. Наприклад: ...Я лиш інструмент, в якому плачуть сни мого народу ... (2, с. 127); I треба все на світі пережити. I кожен фініш - це, по суті старт (2, с. 13).

Слід сказати, що такі асоціації, при всій своїй несподіваності та оригінальності, є загальнозрозумілими. Термінологічні слова в цьому випадку служать для яскравої передачі думки, для створення оригінального художнього образу.

В асоціаціях другого типу використано вже не основне значення терміна, а ті додаткові відтінки, що виникли в ньому поза його первісним застосуванням і дуже часто зумовлені суто суб' єктивним сприйманням: I молодик над смужкою лісів поставить позолочений апостроф (2, с. 328); Старезні пні, кошлаті поторочі, літопис тиші пишуть у траві (2, с. 51); Сосновий ліс перебирає струни над берегами вічної ріки...(2, с. 108); І це вже не декорація... Біла симфонія снігу (2, с. 127).

Найбільш частотними в досліджуваних творах є музичні терміни, 
оскільки 3 ними досить легко пов'язуються не тільки логічні, а й емоційні, експресивні асоціації, як-от: Вечірнє небо світиться красою, $i$ соняхи гудуть як тулумбас (2, с. 95); У гамі дня, в оркестрах децибелів Ми вже були, як хор глухонімих (2, с. 44); Співає ліс захриплими басами, Веде за повід стежечку худу (2, с. 63).

Терміни в поетичних творах Ліни Костенко вживаються разом із словами різних стилістичних категорій для створення яскравих слухових образів: Сосновий ліс перебирає струни. Рокоче тиша на глухих басах (2, с. 108); Вітри гули віолончеллю, писали пальми акварель (2, с. 258).

У цьому разі терміни зберігають лише найзагальніші, нечітко окреслені змістові контури, викликають приблизне уявлення про позначуване поняття. Зазначимо, що особливої експресії набуває термін тоді, коли автор навмисне, із стилістично-виражальною метою вживає його поряд 3 іншостильовими мовними елементами, наприклад, розмовно-побутовими: Поезія згубила камертон. Хтось диригує ліктями ци коліном. Задеренчав $і$ тон, $i$ обертон (2, с. 173); Від магістралі за два метри уся закутана в щзо є, сидить бабуся (2, с. 123).

У наведених прикладах терміни входять до складу переноснометафоричного образу, викликаючи незвичні асоціації. У поєднанні 3 розмовно-побутовими словами вони допомагають витворити цілісні картини світобачення ліричної героїні.

Можна навести багато прикладів, у яких вживається термін 3 означенням, емоційна наснаженість i психологічне забарвлення якого поширюється i на позначуваний терміном нейтральний об'єкт: Bce зарябіло, як газетні ипальти. Бетон, гудрон $і$ пляжнна пастораль (2, с. 102); Приватний атом - істина розщеплена (2, с. 411); Сліпучий магній снігових пустель, Хребтів баских затягнуті попруги (2, с. 104); Старі хати в солом'яних скафандрах Стояли в чорних кратерах села (2, с. 73).

Терміни можуть виступати у функції епітетів, що входять до складних метафоричних утворень. Наприклад: Люстра - електрична сестра орхідей (2, с. 205); За день обличчя сірі, як трепанги. Глухе двигтіння титанічних ступ (2, с.102); Пелюстки скронь - чавунні, як гантелі (2, с. 102).

У своїх поезіях Ліна Костенко практикує вживання спеціальної лексики, активізуючи асоціації, дуже віддалені від прямого значення термінологічних слів, пов'язані 3 тими їхніми властивостями, які для власне термінології випадкові й несуттєві. Такими є, наприклад, асоціації, викликані звуковою формою терміна, його фонетичною близькістю до слів 
інших лексико-семантичних категорій та різної стилістичної маркованості. Зокрема, автор звертається до явища паронімічної атракції: Йдемо крізь ніч, крізь бурю у степу. Крізь дом і сніг, дебати $і$ дебюти (2, с. 6); Вербують верби у монографії. Вивчають біо-і-географію (2, с. 163); Іде епоха моя головата від етики до синтетики (2, с. 181).

Звуковими повторами увиразнюються ключові слова, підсилюються тропи. При цьому, по суті, слово вже не сприймається як термін, як носій чітко окресленого значення і член суворо детермінованої системи понять, оскільки означуваний ним об'єкт у цьому контексті сприймається десь далеко не на першому і навіть не на другому плані, а лише як орнаментальна деталь вибагливого мовного образу.

Іронічного звучання набувають рядки, у яких за допомогою вузькоспеціальних термінів та оказіоналізмів, утворених від термінів, змальовується буденне, апатичне для ліричного героя: Така вона стомлена, анемічна, гіпопотамо-гіпопонічна, волосся фарбоване під мімозу, обличчя в стані анабіозу (2, с. 187).

За допомогою термінів Ліна Костенко створює яскраві порівняння. Наприклад: Душа - єдина на землі держава, Де є свобода чиста, як озон (2, с. 261); I знов летии, як метеор ти. I довго світяться в душі Оті розкішні натюрморти (2, с. 123); А тут ще та комета велетенська, щуо наче в небі схрещені мечі... (2, с. 104).

Поезія Ліни Костенко неповторна саме тим, що в іï творах немає шаблонності, штампу. Допомагає в цьому вживання різноманітних груп термінів, узятих із різних галузей знань. Проте варто зазначити, що серед термінів, уживаних у поетичній мові, значна кількість слів, які відзначаються вузьким термінологічним значенням. Вони не завжди зрозумілі широкому колу читачів. Уведення вузькотермінологічної лексики $\epsilon$, зокрема, ефективним прийомом інтелектуалізації мови поезій, вдалим дієвим засобом залучення читача до світу наукових надбань, пошуків. У подібних випадках точне знання змісту терміна не завжди важливе. Він тут функціонує лише як сигнал «нехудожнього» стилю. I часто цього достатньо. У ситуаціях насичення контексту термінологічною лексикою важить саме звучання слова, сама його фонетична оболонка, як-от: Вивчали скрипку, всю, до міліметра. Вона лежала злякана і мертва. Аналіз, синтез, колби і реторти, алегро, скерцо, модерато, форте, - Немає таємниць під зодіаком (2, с. 248).

Підсумовуючи сказане, відзначимо, що Ліна Костенко досить активно залучає до свого мовного «арсеналу» термінологічну лексику 3 
різних галузей знань. Виділяємо такі шляхи введення термінологічних слів у поетичні тексти: естетична «денейтралізація» спеціальних слів; використання термінологічного слова як компонента метафоричних конструкцій за умови, що основне його значення зберігається і $\epsilon$ основою художнього образу; вживання термінів засноване на асоціаціях, дуже віддалених від прямого значення. Спеціальні слова в поетичних текстах Ліни Костенко - це прагнення поєднати в цілісному образному баченні прадавне народнопоетичне i сучасне науковохудожнє розуміння, спричинене осягненням першооснов, джерел буття.

Оскільки поетичний образ Ліни Костенко головним чином синтезує слово і перецептивні відчуття навколишнього світу (колір, звук, запах, зорові картини тощо), то й відчутно спостерігаємо багатоаспектну трансформацію семантичної структури слова, зокрема слова-терміна.

\section{Література}

1. Катиш Т. В. Особливості функціонування термінологічної лексики в мові української фантастики: автореф. дис. на здобуття наук. ступеня канд. філол. наук: спец. 10.02.01 «Українська мова» / Т. В. Катиш. - Дніпропетровськ: ДДУ, 2005. - 19 с.

2. Костенко Л. В. Вибране / Ліна Василівна Костенко. - К. : Дніпро, 1989. - 559 с.

3. Молодід Г. К. Метафоризація термінів / Г. К. Молодід // Теоретичні проблеми лінгвістичної стилістики. - К. : Наукова думка, 1972. - С.142-149.

4. Терміни в поезіях М. Бажана [Електронний ресурс] / В. І. Мінасян // Режим доступу : www.kulturamovy.org.ua/KM/pdfs/Magazine 25-6.pdf

5. Умерова М. В. Формування і розвиток термінологій та терміносистем [Текст] / М. В. Умерова. - М. : ГУВШ, 2004. - 244 с.

6. Чабаненко В. А. Основи мовної експресії : [монографія] / Віктор Антонович Чабаненко. - К. : Вища школа, 1984. - 169 с.

Стаття надійшла до редакції 17.10.2012 p. 